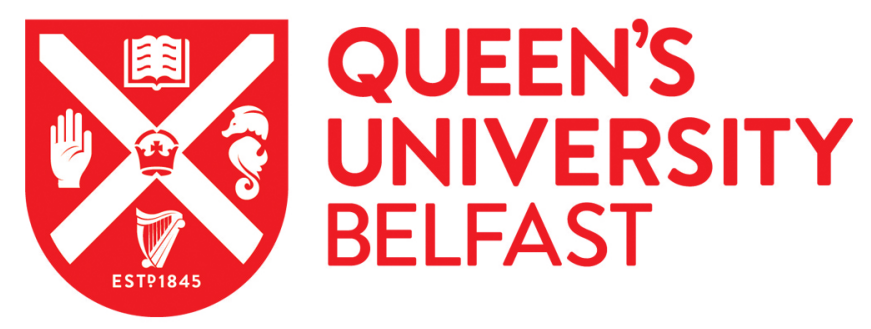

\title{
Reuse of extractive waste from an abandoned mine site: case study of Campello Monti, Italy
}

Mehta, N., Dino, G. A. (Ed.), Passarella, I. (Ed.), Ajmone-Marsan, F. (Ed.), \& De Luca, D. A. (Ed.) (2020). Reuse of extractive waste from an abandoned mine site: case study of Campello Monti, Italy. Abstract from EGU General Assembly 2020, Vienna, Austria. https://doi.org/10.5194/egusphere-egu2020-16506

\section{Document Version:}

Publisher's PDF, also known as Version of record

\section{Queen's University Belfast - Research Portal:}

Link to publication record in Queen's University Belfast Research Portal

\section{Publisher rights}

Copyright 2020 the authors.

This is an open access article published under a Creative Commons Attribution License (https://creativecommons.org/licenses/by/4.0/), which permits unrestricted use, distribution and reproduction in any medium, provided the author and source are cited

\section{General rights}

Copyright for the publications made accessible via the Queen's University Belfast Research Portal is retained by the author(s) and / or other copyright owners and it is a condition of accessing these publications that users recognise and abide by the legal requirements associated with these rights.

Take down policy

The Research Portal is Queen's institutional repository that provides access to Queen's research output. Every effort has been made to ensure that content in the Research Portal does not infringe any person's rights, or applicable UK laws. If you discover content in the Research Portal that you believe breaches copyright or violates any law, please contact openaccess@qub.ac.uk. 
EGU2020-16506, updated on 13 Mar 2021

https://doi.org/10.5194/egusphere-egu2020-16506

EGU General Assembly 2020

(c) Author(s) 2021. This work is distributed under

the Creative Commons Attribution 4.0 License.

\title{
Reuse of extractive waste from an abandoned mine site: case study of Campello Monti, Italy
}

\author{
Neha Mehta ${ }^{1,2}$, Giovanna Antonella Dino ${ }^{1}$, Iride Passarella ${ }^{3}$, Franco Ajmone Marsan ${ }^{4}$, and \\ Domenico De Luca ${ }^{1}$ \\ ${ }^{1}$ University of Torino, Earth Science Department, Torino, Italy (giovanna.dino@unito.it) \\ ${ }^{2}$ School of Mechanical and Aerospace Engineering, Queen's University Belfast, Ashby Building, Stranmillis Road, BT9 5AH, \\ Belfast, UK \\ ${ }^{3}$ Horizon s.r.l., Largo Paolo Braccini, 2, 10095 Grugliasco, Italy \\ ${ }^{4}$ Dipartimento di Scienze Agrarie, Forestali e Alimentari, Università degli Studi di Torino, Largo Paolo Braccini, 2, 10095 \\ Grugliasco, Italy
}

The progress and prosperity have been based on finite mineral resources and fossil fuels. Sustainable development goals of the United Nations and the implementation of the Paris Agreement, resulted in the vast utilization of a wide range of minerals for green technologies such as low-carbon applications. The global demand for raw materials has increased during the last decades (Kinnunen and Kaksonen, 2019).

In addition to clear economic and societal benefits, mining has also created environmental challenges via significant amounts of mining and quarrying waste termed as extractive waste. However, these wastes can be transformed into valuable secondary metal sources combining metals recovery and environmental management.

The current study, focuses on reuse and recovery targeted on extractive waste from abandoned mines in Campello Monti. It is a small settlement of Valstrona village in the northern sector of Piemonte, (NW Italy). Geologically, the site is present in the ultramafic layers of mafic complex of Ivrea Verbano Zone and consists of anorthosites, gabbros, gabbro-norite, Iherzolites, peridotites, pyroxenites, titanolivin. The area was exploited for nickel production from Fe-Ni-Cu-Co magmatic sulphide deposits from 1865 until 1940s. Currently, the area has waste rock and operating residues dumps.

As, the extractive waste from Campello Monti has not been moved from 1940s and recovery trials have also not been performed. Our study dealt with: (1) reusing fine fraction ( $<2 \mathrm{~mm}$ ) of waste rock as soil additive, and (2) recovering raw materials from coarse fraction ( $>2 \mathrm{~mm}$ ) of waste rock and operating residues, by means of dressing methods like wet shaking table and magnetic fraction.

The seed germination and plant growth experiments performed using Blok et al. (2008) showed no major detrimental impact on Lepidium sativum plants. Although the plant growth decreased to $31 \%$ after adding $45 \%$ of waste rock to sand and blonde peat mixture. However, by adding 
fertilizers this can be mitigated to certain extent.

The coarse fraction of waste rock crushed to $<0.5 \mathrm{~mm}$ showed recovery of Co, Cu and $\mathrm{Ni}$ as $53 \%$, $42 \%$ and $66 \%$ using shaking table. Whilst, for the same size and dressing method operating residues depicted recovery of $\mathrm{Co}, \mathrm{Cu}$ and $\mathrm{Ni}$ in the range of $55-76 \%$. Whilst, the recovery of these elements varied from $35-41 \%$ for operating residues and waste rocks using magnetic separation. The micro-XRF mineral mapping of the concentrates obtained from both dressing methods demonstrated presence of pyroxene, pyrrhotite, olivine, magnetite, pentlandite and chalcopyrite.

The present investigation highlights the methodologies used for obtaining raw materials from extractive waste. Thus moving from the linear economy patterns of mineral extraction to circular closed loops.

\section{References}

- Blok, C., Perssone, G., and Wever, G. (2008). A practical and low cost microbiotest to assess the phytotoxic potential of growing media and soil. ISHS Acta Horticulturae 779: International Symposium on Growing Media. 10.17660/ActaHortic.2008.779.46.

- Kinnunen, P.H.-M., and Kaksonen, A.H. (2019). Towards circular economy in mining: Opportunities and bottlenecks for tailings valorization. J. Clean. Prod. 228, 153-160. 